\title{
Incidence of infiltration/extravasation in newborns using peripheral venous catheter and affecting factors
}

\author{
Incidência de infiltração/extravasamento em recém-nascidos usando catéter venoso periférico \\ e fatores correlacionados \\ Incidencia de infiltración/fuga en recién nacidos utilizando catéter venoso periférico y factores \\ correlacionados
}

Selma Atay ${ }^{1}$, Selcen Sen², Dilek Cukurlu²

How to cite this article:

Atay S, Sen S, Cukurlu D. Incidence of infiltration/extravasation in newborns using peripheral venous catheter and affecting factors. Rev Esc Enferm USP. 2018;52:e03360. DOI: http://dx.doi.org/10.1590/S1980-220X2017040103360

${ }^{1}$ Canakkale Onsekiz Mart University, School of Health, Nursing Department, Canakkale, Turkey.

${ }^{2}$ Çanakkale Goverment Hospital, Canakkale, Turkey.

\section{ABSTRACT}

Objective: The objective of this study was to identify the incidence of infiltration and extravasation in newborns using peripheral venous catheter, and affecting factors. Method: This observational study examined catheters inserted into newborns who received inpatient care in the neonatal intensive care unit of a state hospital located in the west of Turkey. A total of 452 peripheral venous catheters inserted into 152 newborns were observed. The forms were completed by the researchers based on their observations at each shift. Results: The infiltration/extravasation occurred in $45.6 \%$ of peripheral venous catheters inserted into newborns; $19.7 \%$ were stage I and $11.7 \%$ were stage IV. A statistically significant relationship was found between the gestation week as well as the birth weight of newborns and the occurrence of infiltration/extravasation complication. In addition, there were statistically significant relationships between the administration of single or multiple antibiotics, total parenteral nutrition and the incidence of infiltration/ extravasation complication. Conclusion: It is recommended to use an appropriate scale for the assessment of infiltration/extravasation as well as to implement measures for preventing the occurrence of infiltration/extravasation.

\section{DESCRIPTORS}

Infant, Newborn; Catheterization, Peripheral; Extravasation of Diagnostic and Therapeutic Materials; Neonatal Nursing. 


\section{INTRODUCTION}

The Neonatal Intensive Care Units (NICUs) are important as they deliver essential care to premature infants and critically ill newborns. Intravenous application is an essential and routine practice to provide nutrition and deliver fluid therapy, blood products and medication to newborns ${ }^{(1-4)}$. Intravenous applications may result in complications such as local and systemic infections, catheter-related infections, phlebitis, infiltration and extravasation ${ }^{(1,5)}$. Injuries caused by extravasation and infiltration are undesirable complications of intravenous therapy. Infiltration is defined as the leak of intravenously administrated materials into surrounding tissues, and the extravasation is defined as the leak of vesicant into surrounding tissue ${ }^{(6-11)}$. The extravasation and infiltration may sometimes cause only minor self-healing complications ${ }^{(12-13)}$, however in other cases it may result in the amputation or loss of muscles, skin and tendon, which may thus require reconstructive surgery ${ }^{(13-14)}$. Furthermore, it is reported to cause prolonged hospitalization, morbidity and increased costs ${ }^{(15-20)}$.

The reported incidence of infiltration is $78 \%$ and the incidence of extravasation is $11 \%$ in newborns ${ }^{(17,21)}$. Around $4 \%$ of injuries from extravasation in the neonatal intensive care unit may result in cosmetic or functional scars ${ }^{(14)}$. Newborns are at particularly high risk for extravasation because of their immature and fragile skin as well as the small diameter of their peripheral veins ${ }^{(5,17,22-23)}$. The newborns are also unable to alter the medical staff to any pain they are suffering, therefore inadvertent continuous infusion increases the risk for extravasation ${ }^{(22,24)}$. A study reported that $0.38 \%$ of extravasation injuries resulted in necrosis in the skin ${ }^{(14)}$. Additionally, a small retrospective review of newborns reported that 6 of the 25 patients had IV infiltrates, which were classified as Stage 4 injuries ${ }^{(3)}$. A study performed with 27 directors of neonatal intensive care units in Australia and New Zealand indicated that $92 \%$ of patients included in the study had severe extravasation injuries ${ }^{(20)}$.

There appears to be no study performed on the rate for infiltration and extravasation in neonatal intensive care units in Turkey. The aim of this study was to identify the rate for infiltration/extravasation in newborns using a peripheral venous catheter (PVC), and the affecting factors.

The main questions of the study are as follows: What is the rate of development of infiltration/extravasation in newborns using a PVC? Is there a relationship between the demographic characteristics of a newborn, their treatment and the rate of development of infiltration/extravasation?

\section{METHOD}

The universe of this prospective observational study comprised of catheters inserted into newborns who received inpatient care in the neonatal intensive care unit of a state hospital located in the west of Turkey between February and December 2015. A total of 452 peripheral venous catheter inserted into 152 newborns were observed. The forms were completed by the researchers based on their observation at each shift. The sample of the study comprised PVCs inserted into newborns who were eligible for inclusion in the study.
Inclusion criteria for the study were: Insertion of a peripheral venous catheter during the period of stay in the neonatal unit, Absence of any systemic illness, Success at first application.

\section{ETHICAL ASPECTS}

Prior to the study, an approval was obtained from the ethics committee of the institution with committee's decision No. 2015-01 dated 07.01.2015. Also, a written permission was obtained from the institution where this study was performed. Before collecting data, the parents of the newborn were explained the objective of this study, and an informed consent form was provided to the parents that agreed to participate in the study and whose newborns met the inclusion criteria.

\section{Data collection}

Data were collected by the Neonate Identification Form developed in line with the literature (gender, medical diagnosis, gestational week, and birth weight), Information Form for Peripheral Venous Catheter and Treatment (catheter number, anatomic insertion site of catheter, antibiotics and fluids used, etc.), and infiltration/extravasation was assessed by the infiltration/extravasation staging instrument developed by Montgomery et al. ${ }^{(6)}$. This instrument, provided below, has five stages for assessment. The PVCs were observed by the researchers at each shift according to an infiltration/extravasation identification form. Each IV attempt was separately observed.

Chart 1 - The infiltration/extravasation staging instrument.

\begin{tabular}{|l|l|}
\hline Stage & \multicolumn{1}{|c|}{ Characteristics } \\
\hline Stage 0 & $\begin{array}{l}\text { Absence of redness, warmth, pain, swelling, blanching, } \\
\text { mottling, tenderness or drainage. Flushes with ease. }\end{array}$ \\
\hline Stage 1 & $\begin{array}{l}\text { Absence of redness, swelling. } \\
\text { Flushes with difficulty. } \\
\text { Pain at site. }\end{array}$ \\
\hline Stage 2 & $\begin{array}{l}\text { Slight swelling at site. } \\
\text { Presence of redness. } \\
\text { Pain at site. } \\
\text { Good pulse below site. } \\
\text { 1-2 second capillary refill below site. }\end{array}$ \\
\hline Stage 3 & $\begin{array}{l}\text { Moderate swelling above or below site. Blanching. } \\
\text { Pain at site. } \\
\text { Good pulse below infiltration site. } \\
\text { 1-2 second capillary refill below site. } \\
\text { Skin cool to touch. }\end{array}$ \\
\hline Stage 4 & $\begin{array}{l}\text { Severe swelling above or below site. } \\
\text { Blanching. } \\
\text { Pain at site. } \\
\text { Decreased or absent pulse. } \\
\text { Capillary refill greater than 4 seconds. } \\
\text { Skin cool to touch. } \\
\text { Skin breakdown or necrosis. }\end{array}$ \\
\hline
\end{tabular}

Source: Montgomery et al. $1999^{(6)}$.

\section{DATA ANALYSIS}

The study data were analyzed by a computer program. The effects of factors affecting the development of infiltration/extravasation were assessed by chi-square and logistic regression analysis. 


\section{RESULTS}

Of the newborns included in this study, $60.6 \%$ were male, $54.4 \%$ had a gestational week greater than 37 , and $38.3 \%$ had a low birth weight ranging 1,500 to 2,499 g., $55.1 \%$ of catheters were inserted through upper surface of the hand, and $20.8 \%$ of them were inserted through the feet. The Number 24-26 gauge catheter was used on all newborns. Of the patients, $65.2 \%$ received multiple antibiotics and $53.0 \%$ received TPN (Total Parenteral Nutrition).

No complications were observed in $54.4 \%$ of PVCs, but infiltration/extravasation was observed in $45.6 \%$ of PVCs. Of the infiltration/extravasation observed, $19.7 \%$ were stage I, $13.5 \%$ were stage II, and $11.7 \%$ were stage IV.

A comparison of the incidence of infiltration/extravasation with several variables is provided in Figure 1. In Table 1, there is a statistically significant relationship between the gestational week as well as birth weight of the newborn and the incidence of infiltration/extravasation. We also found a statistically significant relationship between the method of antibiotic therapy (i.e., single or multiple), the delivery of TPN and the infiltration/extravasation.

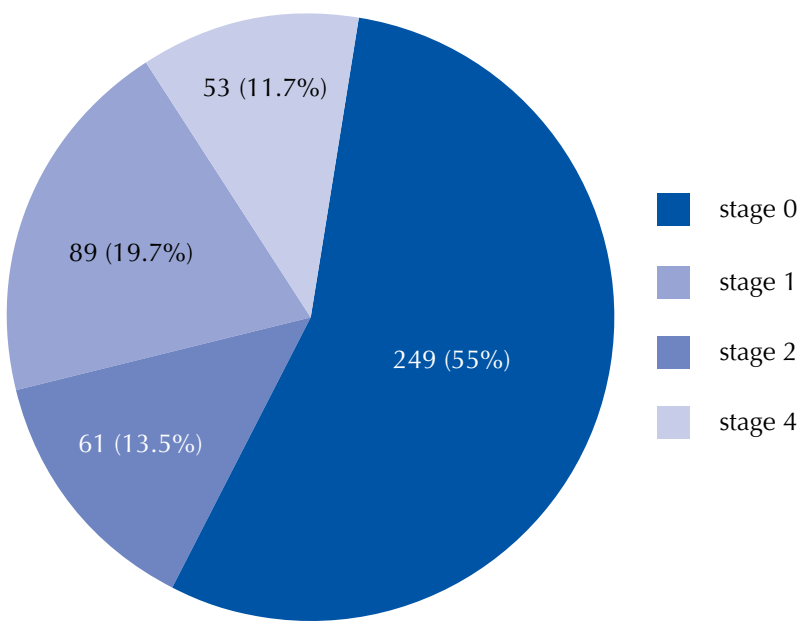

Figure 1 - Distribution of results of infiltration/extravasation in peripheral venous catheters observed for study - Canakkale, Turkey, 2015.

Table 1 - Comparison of incidence of infiltration/extravasation with several variables - Canakkale, Turkey, 2016.

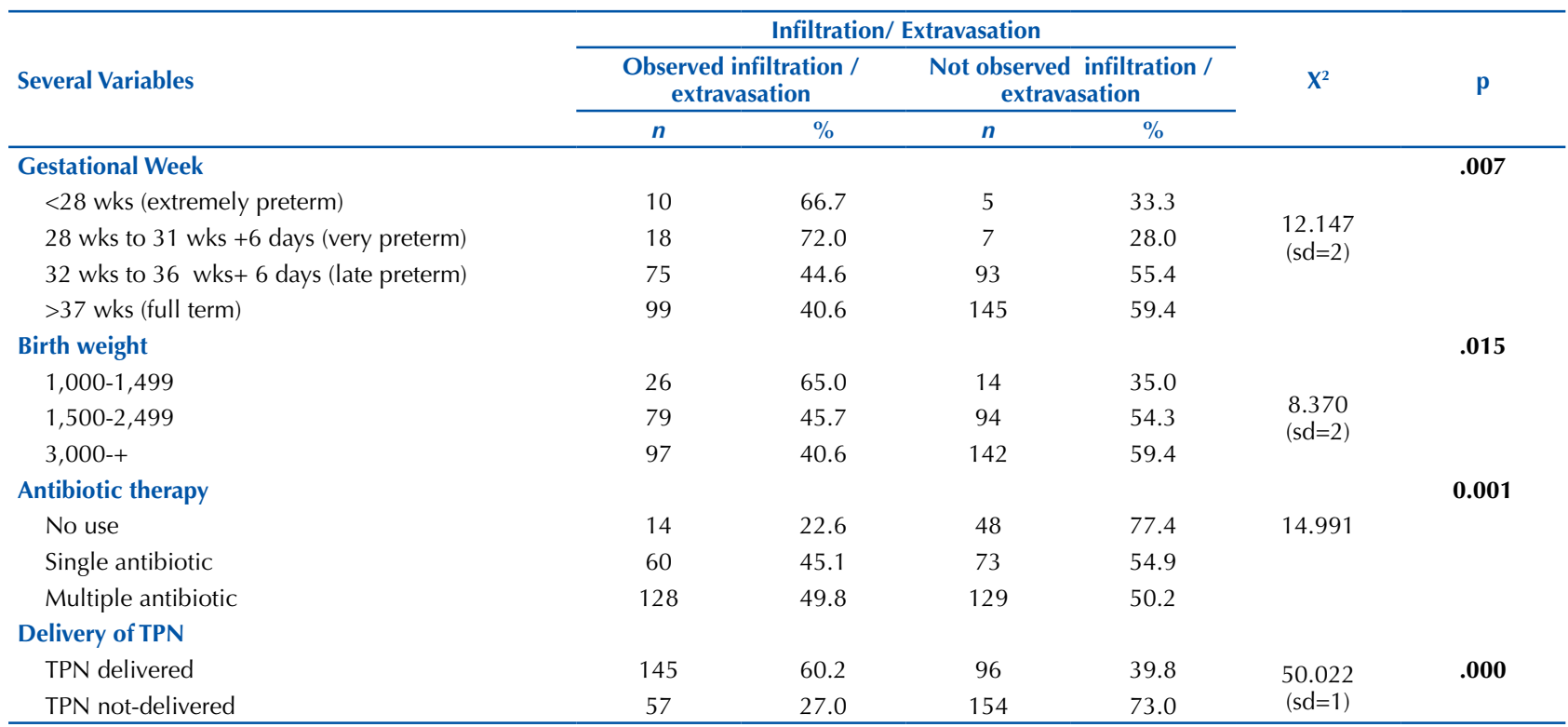

Note: TPN= Total Parenteral Nutrition.

\section{DISCUSSION}

Infiltration/extravasation was observed in $45.6 \%$ of peripheral venous catheters placed into the newborns under study; $19.7 \%$ were stage I and $11.7 \%$ were stage IV. A study used the scale adapted by the research committee of pediatric nurses for their study and found that the stage of infiltration/extravasation was mostly stage $0(n=11)$ and stage $4(n=6)^{(3)}$. In the reported cases, the rate of infiltration appears to be $57 \%$ to $70 \%$ and the rate of extravasation ranges from $11 \%$ to $23 \%{ }^{(25)}$. The rate of infiltration/extravasation was reported as $69.8 \%$, according to data ${ }^{(26)} .92 \%$ of nurses underlined that they encountered severe injuries of extravasation ${ }^{(20)}$. A study performed in the neonatal intensive care unit found an infiltration rate of $67 \%{ }^{(27)}$.

In the present study, a significant difference was found between the gestational week and the assessment findings of infiltration/extravasation $\left(X^{2}=12.147, s d=2, p<0.05\right)$. In the further analysis, it was found that the difference can be attributed to newborns who underwent very preterm and extremely preterm birth. In a similar study, a significant relationship was found between gestational week and skin necrosis ${ }^{(27)}$. In another study, it was reported that $70 \%$ of extravasation injuries occurred in individuals born at 
or before their 26 th of gestational week ${ }^{(14)}$. Compared to their mature and healthy peers, the preterm and sick newborns are more likely to have skin injury and complications caused by extravasation injury because of their comparatively immature skin structure, flexible subcutaneous tissue, small veins and poor venous integrity. These factors increase the risk of complication resulted from venipuncture and IV infusions ${ }^{(3,28-29)}$. However, in a descriptive study, no relationship was found between the gestational week and the extravasation stage ${ }^{(3)}$.

In our study a statistically significant difference between the birth weight and the prevalence of infiltration/extravasation was detected $\left(\mathrm{X}^{2}=8.370\right.$, $\mathrm{sd}=2$, $\mathrm{p}<0.05)$. In the further analysis made, this difference was found to originate from the group with a birth weight of 1,000-1,499. Having a birth weight of 1,000-1,499 increases the risk of infiltration/extravasation frequency 1.9 fold (OR: $1.91 \mathrm{Cl}$ : 1.276-2.849). In the literature, there are different results regarding the relation between birth weight and infiltration/extravasation frequency. Although a significant relationship was found between birth weight and extravasation injuries in one study ${ }^{(27)}$, which is similar to our study, no relationship between birthweight of neonates and extravasation stage was detected in another one ${ }^{(3)}$.

In this study, a statistically significant difference was found between the application of single or multiple antibiotics, TPN application and infiltration/extravasation frequency $\left(X^{2}=4.991, s d=2, p<0.05 ; X^{2}=50.022, s d=1, p<0.05\right)$.
In the further analysis carried out, while multiple antibiotic usage was found to increase the risk factor in double (OR: $1.877 \mathrm{Cl}$ : 1.247-3.471), TPN application was found to increase the risk factor about three times (OR: $2.91 \mathrm{Cl}$ : 1.801-4.704). In the study results, it was stated that the majority of neonates use TPN and calcium ${ }^{(3)}$. In a further study, extravasation development was detected in all cases treated with $10 \%$ glucose and calcium chloride ${ }^{(30)}$. In a study conducted in 38 regional neonatal intensive care units in the United Kingdom, it was found that $50 \%$ of injuries are due to $\mathrm{TPN}^{(14)}$. In one study, it was reported that severe skin damage occurred after TPN infusion ${ }^{(27)}$. In another study, a relationship between infiltration/extravasation and the type of infusion along with medications and infusion solution was found ${ }^{(26)}$.

\section{CONCLUSION}

Based on the study results, it appears that the rate of infiltration/extravasation was high (45.6\%) in newborns using a peripheral venous catheter. Infiltration/extravasation is a preventable complication of peripheral intravenous catheter. It is recommended that medical staff be aware of factors which cause the development of infiltration to ensure a safe peripheral intravenous catheterization, and take the necessary measures based on such factors to regularly assess and document the site using a scale, to identify the infiltration/extravasation early and to implement the proper care when developed.

\section{RESUMO}

Objetivo: $O$ objetivo deste estudo foi identificar a incidência de infiltração e extravasamento em recém-nascidos usando catéter venoso periférico e fatores correlacionados. Método: Este estudo observacional examinou catéteres inseridos em recém-nascidos que estavam internados na unidade de terapia intensiva neonatal de um hospital estadual localizado no oeste da Turquia. Um total de 452 catéteres venosos periféricos inseridos em 152 recém-nascidos foram observados. Os formulários foram completados pelos pesquisadores com base nas suas observações em cada turno. Resultados: A infiltração/extravasamento ocorreu em $45,6 \%$ dos catéteres venosos periféricos inseridos em recém-nascidos; $19,7 \%$ eram estágio I e $11,7 \%$ eram estágio IV. Uma relação estatisticamente significativa foi encontrada entre a semana gestacional, bem como o peso ao nascer dos recém-nascidos, e a ocorrência de complicação de infiltração/extravasamento. Além disso, houve relações estatisticamente significativas entre a administração de um ou vários antibióticos, nutrição parenteral total e a incidência de complicação de infiltração/extravasamento. Conclusão: É recomendado o uso de uma escala apropriada para a avaliação da infiltração/extravasamento, bem como implantar medidas para a prevenção da ocorrência de infiltração/extravasamento.

\section{DESCRITORES}

Recém-Nascido; Cateterismo Periférico; Extravasamento de Materiais Terapêuticos e Diagnósticos; Enfermagem Neonatal.

\section{RESUMEN}

Objetivo: El objetivo de este estudio fue identificar la incidencia de infiltración y fuga en recién nacidos utilizando catéter venoso periférico y los factores correlacionados. Método: Este estudio observacional examinó los catéteres introducidos en recién nacidos que estaban en estancia hospitalaria en unidad de cuidados intensivos neonatales de un hospital ubicado en el oeste de Turquía. Un total de 452 catéteres venosos periféricos introducidos en 152 recién nacidos fueron observados. Los formularios fueron rellenados por los investigadores con base en sus observaciones en cada turno. Resultados: La infiltración/fuga ocurrió en el 45,6\% de los catéteres venosos periféricos introducidos en recién nacidos; el 19,7\% eran estadío I y el 11,7\% eran estadío IV. Una relación estadísticamente significativa fue encontrada entre la semana gestacional, así como el peso al nacer de los recién nacidos, y la ocurrencia de complicación de infiltración/fuga. Además, hubo relaciones estadísticamente significativas entre la administración de uno o varios antibióticos, nutrición parenteral total y la incidencia de complicación de infiltración/fuga. Conclusión: Se recomienda el empleo de una escala apropiada para la evaluación de la infiltración/fuga, así como implantar medidas para la prevención de la ocurrencia de infiltración/fuga.

\section{DESCRIPTORES}

Recién Nacido; Cateterismo Periférico; Extravasación de Materiales Terapéuticos y Diagnósticos; Enfermería Neonatal. 


\section{REFERENCES}

1. Davies J, Gault D, Buchdahl R. Preventing the scars of neonatal intensive care. Arch Dis Child Fetal Neonatal Ed. 1994;70(1):F50-1.

2. Hermansen MC, Hermansen MG. Intravascular catheter complications in the Neonatal Intensive Care Unit. Clin Perinatol. 2005;32(1):141-56.

3. McCullen KL, Pieper B. A retrospective chart review of risk factors for extravasation among neonates receiving peripheral intravascular fluids. J Wound Ostomy Continence Nurs. 2006;33(2):133-9.

4. Beall V, Hall B, Mulholland JT, Gephart SM. Neonatal extravasation: an overview and algorithm for evidence-based treatment. Newborn Infant Nurs Rev. 2013;13(4):189-95.

5. Warren D. Implementation of a protocol for the prevention and management of extravasation injuries in the neonatal intensive care patient. Int J Evid Based Healthc. 2011;9(2):165-71.

6. Montgomery LA, Hanrahan K, Kottman K, Otto A, Barrett T, Hermiston B. Guideline for i.v. infiltrations in pediatric patients. Pediatr Nurs. 1999;25(2):167-9, 173-80.

7. Infusion Nurses Society. Infusion nursing standards of practice. J Infus Nurs. 2016;39(1Suppl):S1-92.

8. Dougherty L. IV therapy: recognizing the differences between infiltration and extravasation. Br J Nurs. 2008;17(14):896, 898-901.

9. Polovich M, White JM, Kellher LO, editors. Chemotherapy and biotherapy guidelines and recommendations for practice. $2^{\text {nd }}$ ed. Pittsburgh, PA: Oncology Nursing Society; 2005.

10. Amjad I, Murphy T, Nylander-Housholder L, Ranft A. A new approach to management of intravenous infiltration in pediatric patients: pathophysiology, classification, and treatment. J Infus Nurs. 2011;34(4):242-9.

11. Dychter SS, Gold DA, Carson D, Haller M. Intravenous therapy: a review of complications and economic considerations of peripheral access. J Infus Nurs. 2012;35(2):84-91.

12. Bellin MF, Jakobsen JA, Tomassin I, Thomsen HS, Morcos SK, Thomsen HS, et al. Contrast medium extravasation injury: guidelines for prevention and management. Eur Radiol. 2002;12(11):2807-12.

13. McManus J, Lund C, Nonato L. Neonatal integumentary system. In: Ross Pediatric Clinical Education Series; 2002.

14. Wilkins CE, Emmorson AJB. Extravasation injuries on regional neonatal units. Arch Dis Child Fetal Neonatal Ed. $2004 ; 89(3)$ :F274-5.

15. Liau DW. Injuries and liability related to peripheral catheters: a closed claims analysis. Newsl Am Soc Anesthesiol [Internet]. 2006 [cited 2017 Aug 15];70(6):11. Available from: http://monitor.pubs.asahq.org/article.aspx?articleid=2489785

16. Cisler-Cahill L. A protocol for the use of amorphous hydrogel to support wound healing in neonatal patients: an adjunct to nursing skin care. Neonatal Netw. 2006;25(4):267-73.

17. Thigpen JL. Peripheral intravenous extravasation: nursing procedure for initial treatment. Neonatal Netw. 2007;26(6):379-84.

18. Diehl-Svrjcek BC, Dawson B, Duncan LL. Infusion nursing: aspects of practice liability. J Infus Nurs. 2007;30(5):274-9.

19. Hadaway L. Infiltration and extravasation. Am J Nurs. 2007;107(8):64-72. Erratum in: Am J Nurs. 2007;107(10):15.

20. Restieaux M, Maw A, Broadbent R, Jackson P, Barker D, Wheeler B. Neonatal extravasation injury: prevention and management in Australia and New Zealand-a survey of current practice. BMC Pediatr [Internet]. 2013 [cited 2017 Aug 15];13:34. Available from: https://www. ncbi.nlm.nih.gov/pmc/articles/PMC3599986/

21. Flemmer L, Chan JS. A pediatric protocol for management of extravasation injuries. Pediatr Nurs. 1993;19(4):355-8, 424.

22. Franck LS, Hummel D, Connell K, Quinn D, Montgomery J. The safety and efficacy of peripheral intravenous catheters in ill neonates. Neonatal Netw. 2001;20(5):33-8.

23. Tong R. Preventing extravasation injuries in neonates. Paediatr Nurs. 2007;19(8):22-5.

24. Dougherty L. Extravasation: prevention, recognition and management. Nurs Stand. 2010;24( 52):48-55.

25. Wynsma LA. Negative outcomes of intravascular therapy in infants and children. AACN Clin Issues. 1998;9(1):49-63.

26. Danski MT, Mingorance P, Johann DA, Vayego SA, Lind J. Incidence of local complications and risk factors associated with peripheral intravenous catheter in neonates. Rev Esc Enferm USP. 2016;50(1):22-8. DOI: 10.1590/S0080-623420160000100003

27. Kostogloudis N, Demiri E, Tsimponis A, Dionyssiou D, loannidis S, Chatziioannidis I, et al. Severe extravasation injuries in neonates: a report of 34 cases. Pediatr Dermatol. 2015;32(6):830-5.

28. Lund C, Brandon D, Holden A, Kuller C, Hill C, Bingham D, et al. Neonatal skin care third edition: evidence-based clinical practice guideline. $3^{\text {rd }}$ ed. Washington: Association of Women's Health, Obstetric and Neonatal Nurses; 2015.

29. Legemaat M, Carr PJ, van Rens RM, van Dijk M, Poslawsky IE, van den Hoogen A. Peripheral intravenous cannulation: complication rates in the neonatal population: a multicenter observational study. J Vasc Access. 2016;17(4):360-5.

30. Nandiolo-Anelone KR, Allah KC, Cissé L, Bankolé SR, Oulaï M, Aké AY. Extravasation injuries in newborns: our experience about 15 cases. Chir Main. 2014;33(1):44-50. 